Bartosz Kaźmierczak, Dominika Pazder

Politechnika Poznańska, Wydział Architektury

e-mail: bartosz.kazmierczak@put.poznan.pl, dominika.pazder@put.poznan.pl

\title{
Tworzenie „miejsc kompletnych” w procesie nauczania projektowania urbanistycznego zorientowanego na rozwiązywanie realnych problemów przestrzennych. Przykład działań podejmowanych na Wydziale Architektury Politechniki Poznańskiej
}

\begin{abstract}
Zarys treści: Artykuł przedstawia wybrane zagadnienia związane z projektowaniem „miejsc kompletnych" - rozumianych jako przyjazne i atrakcyjne społecznie przestrzenie publiczne. Podkreślono ważność włączania do procesu projektowego lokalnych społeczności, by opracowywane koncepcje projektowe w jak największym stopniu odpowiadały realnym potrzebom. W artykule ukazano ideę kreowania „miejsc kompletnych” stanowiącą element procesu dydaktycznego realizowanego na Wydziale Architektury Politechniki Poznańskiej i w ramach współpracy z otoczeniem zewnętrznym. Zaprezentowany przykład uczenia się opartego na współpracy przy rozwiązywaniu realnych problemów przestrzennych wydaje się przydatnym narzędziem służącym promowaniu idei planowania uspołecznionego oraz poprawy jakości przestrzeni wspólnej. Przedstawiony został przykład badawczy długotrwałej współpracy między instytutami akademickimi a gminą Tarnowo Podgórne, w rezultacie której powstaje kompleks obiektów wraz z otaczającą przestrzenią publiczną, którego celem jest integracja i budowanie wspólnoty obywatelskiej wśród lokalnej społeczności.
\end{abstract}

Słowa kluczowe: projektowanie miejsc kompletnych, planowanie uspołecznione, projektowanie włączające i zorientowane na problemie

\section{Wprowadzenie}

Podjęte w artykule zagadnienia dotyczą dwóch aspektów - planowania przestrzennego $z$ udziałem społecznym w celu zapewnienia pożądanej atrakcyjności ze szczególnym uwzględnieniem przestrzeni publicznej oraz nauczania projektowania urbanistycznego realizowanego $\mathrm{w}$ formie collaborative i problem-based learning. Zaprezentowana $\mathrm{w}$ artykule współpraca $\mathrm{z}$ otoczeniem zewnętrznym stanowi 
przykład przedsięwzięcia realizowanego przez autorów w ramach prowadzonej pracy dydaktycznej i naukowej.

Projektowanie włączające i współuczestniczące, a także orientacja działań dydaktycznych na rozwiązywanie realnych problemów przestrzennych stanowi kluczowy aspekt nauczania urbanistycznego realizowanego na Wydziale Architektury Politechniki Poznańskiej. Jest to też rodzaj współpracy nauki z otoczeniem zewnętrznym - władzami miast i gmin Wielkopolski oraz lokalnymi społecznościami. Kolejnym istotnym dla autorów zagadnieniem jest wdrażanie idei complete places visioning ${ }^{1}$ - tworzenia miejsc kompletnych pod względem przestrzennym, funkcjonalnym i semantycznym. Szczególnie ważna jest sama definicja słowa „miejsce”, które rozumiane jest jako przestrzeń społecznie akceptowana, o czytelnym charakterze i tożsamości. Takie ujęcie podkreśla równoważność dwóch aspektów atrakcyjności przestrzennej i społecznej, a także wiąże się z realizacją paradygmatu planowania partycypacyjnego oraz idei placemaking ${ }^{2}$, czyli tworzenia przestrzeni dla ludzi i przez ludzi, którzy mają być w przyszłości jej najważniejszymi użytkownikami.

Projekty realizowane w ramach kilkuletniej współpracy Wydziału Architetury Politechniki Poznańskiej z Instytutem Haverford Publicznej Socjologii dotyczyły identyfikacji uwarunkowań i zdefiniowania innowacyjnych kierunków rozwoju gminy i wsi Tarnowo Podgórne. Celem współdziałania było wypracowanie rozwiązań projektowych, które mogą przyczynić się do wzrostu atrakcyjności przestrzennej i konkurencyjności ofertowej na tle województwa wielkopolskiego. Opracowania planistyczne odnosiły się do wybranych przestrzeni strategicznych, stanowiących duży potencjał rozwojowy, i ich powiązań funkcjonalno-przestrzennych z innymi jednostkami osadniczymi gminy, promując zasadę synergicznej współpracy i wzmacniania marki miejsca. Projekty urbanistyczno-architektoniczne miały na celu wskazanie bardzo konkretnych rozwiązań, których głównym założeniem było podniesienie jakości przestrzeni publicznych centrum Tarnowa Podgórnego, a także stworzenie miejsca służącego aktywizacji i integracji lokalnej społeczności - kompleksu budynków Centrum Aktywizacji Obywatelskiej.

Prezentowane działania mają na celu propagowanie szeroko rozumianego uspołecznienia procesu planistycznego i promocję idei projektowania włączającego. Wymiana myśli i doświadczeń, inspirowanie kreatywności oraz współpraca różnych aktorów procesu planistycznego - włodarzy i lokalnych społeczności, ośrodków akademickich i inwestorów - to bardzo dobre narzędzie kierunkowania procesów odnowy oraz skuteczny instrument do tworzenia miejsc przyjaznych, atrakcyjnych i pożądanych społecznie, które cechują się wysoką jakością użytkową i estetyczną, a przede wszystkim odpowiadają na realne potrzeby i aspiracje użytkowników.

"Complete places i active inner city space - wybrane zagadnienia kształtowania żywotnych i wysokiej jakości przestrzeni publicznych w obszarach śródmiejskich", 2018, temat badawczy 10/04/ DSPB/0140, etap I, realizowany w ramach Działalności Statutowej w Instytucie Architektury, Urbanistyki i Ochrony Dziedzictwa, kierownik tematu - dr inż. arch. B. Kaźmierczak, członek zespołu - dr inż. arch. Dominika Pazder.

2 https://www.pps.org/article/what-is-placemaking 


\section{Projektowanie „miejsc kompletnych” - complete places visioning}

Prezentowane rozważania dotyczą wybranych przykładów redefinicji i aranżacji przestrzeni otwartych ze szczególnym uwzględnieniem przestrzeni publicznych, które według autorów powinny być wysokiej jakości funkcjonalnej, pełne semantycznie i przyjazne społecznie. To właśnie jakość przestrzeni publicznych wpływa na ocenę atrakcyjności przestrzeni miejskiej i jej żywotność. Punktem wyjścia podjętych rozważań jest rozumienie architektury, w tym urbanistyki, jako zdolności kształtowania otoczenia człowieka. Kluczowe jest uwzględnienie wieloaspektowości uwarunkowań, nie tylko przestrzennych, funkcjonalnych i ekonomicznych, ale też zagadnień humanistycznych, kulturowych i społecznych. Complete places visioning rozumiane jest jako kreowanie atrakcyjnej i aktywnej społecznie przestrzeni publicznej, o wysokiej jakości estetycznej i kompozycyjnej, która wpływa na zapewnienie pozytywnych doznań emocjonalnych, komfortu psychofizycznego oraz stwarza szerokie możliwości nawiązywania kontaktów społecznych.

$\mathrm{Z}$ punktu widzenia tworzenia przestrzeni kompletnych, atrakcyjnych przestrzennie i aktywnych społecznie, zdaniem autorów warto wziąć pod uwagę trzy elementy, które w istotny sposób wpływają na jakość przestrzeni publicznych. Pierwszym elementem jest kompozycja przestrzenna, która odgrywa istotną rolę w ocenie jakości przestrzeni miejskiej przez użytkownika, a także decyduje o stopniu atrakcyjności i zapewnieniu pożądanej harmonii przestrzennej. Kompozycja uwypukla zastane wartości: specyfikę miejsca, tożsamość kulturową i fizjonomiczną oraz prestiż społeczny i kulturowy. Drugim ważnym czynnikiem zapewniania odpowiedniej jakości przestrzeni publicznej jest właściwie dobrana oferta funkcjonalna - w tym związana $z$ kulturą i zapewniająca odpowiednie zaplecze w postaci funkcji kulturotwórczych. Szeroko rozumiana działalność kulturalna może w znacznym stopniu przyczynić się do aktywizacji lokalnych społeczności i wzmacniania więzi mieszkańców z przestrzenią poprzez: generowanie społecznego zaangażowania, rozwijanie poczucia dumy, kreowanie wizerunku i tożsamości miasta, tworzenie atrakcyjnych miejsc do mieszkania, odwiedzania i inwestowania, realizowanie projektów kulturalnych, które aktywizują rozwój (Sanetra-Szeliga 2013, s. 415). Trzecim elementem jest odpowiednie wyposażenie przestrzeni miejskiej. W kontekście tworzenia wysokiej atrakcyjności przestrzeni publicznej należy zadbać o właściwą formę i jakość wizualną tych elementów, które oprócz swych oczywistych funkcji użytkowych powinny prezentować odpowiedni poziom estetyczny. Wprowadzanie elementów małej architektury powinno być dostosowane do otoczenia, zgodne $z$ jego dramaturgią i charakterem przestrzennym. Specyfika wyposażenia urbanistycznego polega na tym, że stanowi ono materiał do kształtowania wizerunku przestrzeni publicznej zarówno pod względem estetycznym, jak i atrakcyjności oferty funkcjonalnej.

W kontekście powyższych rozważań planowanie partycypacyjne stanowi wart podkreślenia instrument kreowania przestrzeni wspólnej, w którym kluczową rolę odgrywa rzeczywisty udział i zaangażowanie mieszkańców. Idea tworzenia miejsc - placemaking - jest także rodzajem planowania uspołecznionego, w którym 
nacisk położony jest na kreowanie znaczeń. Pojęcie miejsca postrzegane jest w kategoriach odczuwania przestrzeni fizycznej, której użytkownicy przypisują określone cechy symboliczne i emocjonalne (Dovey 1985), a relacja między przestrzenią a jej odbiorcą jest bardzo istotna. Miejsce może być definiowane jako rezultat zależności między atrybutami fizycznymi i aktywnościami wiążącymi się $z$ daną przestrzenią (Canter 1977). Nawiązując do metafory miejsca, można wskazać na trzy najważniejsze elementy, które je charakteryzują (Montgomery 2003): aktywność (ekonomiczna, kulturowa, społeczna), forma (odpowiednie relacje między tkanką zabudowaną a przestrzeniami publicznymi) oraz poczucie miejsca (jego znaczenie historyczne i rola kulturotwórcza). Podobne cechy podkreśla Auge (1995), który definiuje miejsca jako przestrzenie o określonej tożsamości, pełne semantycznie i aktywne społecznie, odróżniając je od przestrzeni nijakich i trudnych do zdefiniowania, które określa mianem nie-miejsc. Autorzy szczególną uwagę skupiają na zagadnieniu kreowania miejsc przyjaznych i pełnych, podkreślając ważność koncepcji wytwarzania miejsc, która stanowi jedną z ważniejszych idei w projektowaniu urbanistycznym i architektonicznym (Dober 1992). Placemaking - wytwarzanie miejsc - wiąże się także z założeniami interdyscyplinarnej nauki - ekistyki (Doxiadis 1968). Zapoczątkowana w latach 60. ubiegłego wieku, dotyczy problematyki kreowania przestrzeni przyjaznej, która sprzyja ludzkiej egzystencji, zapewniając właściwą harmonię między otoczeniem fizycznym a środowiskiem społeczno-kulturowym.

W ujęciu współczesnym rola projektowania i designu jest postrzegana w bardzo szerokim kontekście: jako aktywność interdyscyplinarna, włączająca, spekulatywna czy dyskursywna (Clarke 2016, s. 70). W odniesieniu do prezentowanych w pracy rozważań projektowanie tymczasowe i angażujące może stanowić narzędzie kreowania przestrzeni aktywnej i elastycznej, odpowiadającej na zmienne potrzeby społeczne i uwarunkowania funkcjonalne, przyczyniając się do tworzenia wysokiej jakości i kompletnej przestrzeni publicznej. Takie podejście do rozwiązywania problemów przestrzennych w ramach projektowania włączającego jest bliskie koncepcji projektowania interwencyjnego (design intervention), która jest metodą pozwalającą na odkrycie i zastosowanie nowych sposobów doświadczania przestrzeni, inspirowania dialogu i interakcji społecznych, z uwzględnieniem złożoności procesów rozwojowych. Design intervention jest elementem projektowania eksperymentalnego (experimental design), w którym najważniejsze jest przyjęcie określonej perspektywy i horyzontu czasowego oraz dokonanie analizy i ewaluacji spodziewanych efektów jej wdrożenia. Tego typu projektowanie ma z założenia balansować na granicy realności i fikcji, pobudzając tym samym kreatywność i wyobraźnię uczestników procesu. Jest to swoiste narzędzie badawcze z pogranicza etnografii i sztuk projektowych, pozwalające na wykorzystanie rozwiązań nieoczywistych, ulotnych umożliwiających wymianę myśli, poglądów i opinii, jednocześnie zwiększające świadomość i poziom społecznego współżycia (Halse, Boffi 2016). 


\section{Tworzenie miejsc jako główny przedmiot projektowania włączającego. Przykład gminy Tarnowo Podgórne w województwie wielkopolskim}

Prezentowane przedsięwzięcia dotyczą wykorzystania zasobów intelektualnych i twórczych studentów Wydziału Architektury Politechniki Poznańskiej w ramach współdziałania z gminą Tarnowo Podgórne i organizacją pozarządową - Instytutem Haverford Publicznej Socjologii ${ }^{3}$. Jest to bardzo dobry przykład współpracy środowiska naukowego z otoczeniem zewnętrznym, który przynosi wiele korzyści dla obu stron. Przede wszystkim gmina uzyskuje czytelny graficznie materiał, który może stanowić ważne i pomocne narzędzie w dyskusji na temat jej przyszłego zagospodarowania i możliwości rozwojowych. Z punktu widzenia ośrodka akademickiego wielką wartość stanowi współpraca z osobami zainteresowanymi rozwiązaniem konkretnego problemu przestrzennego oraz znającymi uwarunkowania danej przestrzeni. Dużym atutem jest możliwość zorientowania nauczania akademickiego na praktyczne potrzeby miejsca i poszukiwanie rozwiązań dostosowanych do realnych możliwości.

Współpraca Instytutu Haverford Publicznej Socjologii z władzami gminy Tarnowo Podgórne i poznańskimi ośrodkami akademickimi jest przykładem planowania uspołecznionego. Kilkuletnie badania urbanistyczno-społeczne prowadzone na dwóch uczelniach poznańskich służyły identyfikacji i ewaluacji istniejących zasobów funkcjonalno-przestrzennych i możliwości rozwojowych gminy i wsi. Badania były przedmiotem pracy dydaktycznej realizowanej na Wydziale Architektury oraz w Instytucie Socjologii na Wydziale Nauk Społecznych. Badania socjologiczne polegały m.in. na przeprowadzeniu ankiet służących identyfikacji potrzeb mieszkańców, a także wywiadów i kwestionariuszy skierowanych do przedstawicieli Rady Gminy. Efektem tych działań było sformułowanie rekomendacji w zakresie potrzeb funkcjonalno-przestrzennych i społecznych, które były podstawą do opracowania wytycznych do dwóch konkursów - urbanistycznego i architektonicznego skierowanych do studentów Wydziału Architektury Politechniki Poznańskiej. Przygotowane przez studentów prace były prezentowane na wystawach i oceniane w publicznych plebiscytach. Dzięki otwartej dyskusji zrealizowany został postulat planowania partycypacyjnego, który umożliwił wypracowanie konsensusu i zapewnienie właściwego kierunku rozwoju przestrzennego w postaci spójnej dla mieszkańców i władz wizji rozwojowej.

W przypadku współpracy między Wydziałem Architektury a gminą Tarnowo Podgórne głównym założeniem collabrative i problem-based learning było znalezienie sposobu na zmianę wizerunku poprzez podniesienie jakości oraz rozszerzenie

\footnotetext{
Instytut Haverford Publicznej Socjologii (IHPS) to fundacja non profit działająca w Stanach Zjednoczonych i w Polsce. IHPS wykorzystuje socjologię i nauki społeczne do angażowania szerszej społeczności we wprowadzanie innowacyjnych, oddolnych rozwiązań problemów społecznych. Dr Slawomira Zbierski-Salameh jest założycielką i przewodniczącą Instytutu Haverford Publicznej Socjologii, jest także członkinią American Sociological Association (ASA) oraz International Sociological Association (ISA).
} 
oferty przestrzeni publicznych w centralnej części wsi Tarnowo Podgórne. Przestrzenie te pełnią istotną rolę kompozycyjną, funkcjonalną i społeczną, ale ich zagospodarowanie oraz jakość estetyczna nie są zadowalające. Ważnym zagadnieniem jest potrzeba aktywizacji społecznej i obywatelskiej mieszkańców oraz zapewnienie im atrakcyjnego pod względem formalnym i funkcjonalnym miejsca do realizowania aktywności, interakcji i kontaktów społecznych. Inicjatorem współpracy była organizacja pozarządowa - Instytut Haverford Publicznej Socjologii, który stał się głównym katalizatorem wszystkich działań i animatorem długotrwałej kooperacji. Wieloetapowa i kilkuletnia działalność zmierzająca do zdefiniowania kierunków rozwojowych w różnych skalach szczegółowości - od poziomu gminy, przez skalę wsi, aż po skalę architektoniczną - zaowocowała uzyskaniem czytelnego materiału graficzno-tekstowego, który stał się przyczynkiem do dyskusji i rozważań na temat przyszłego zagospodarowania. Najważniejszym efektem tych działań jest realne wdrożenie wypracowanych wytycznych w formie realizacji inwestycji w centrum wsi Tarnowo Podgórne służącej aktywizacji społecznej i budowaniu świadomości obywatelskiej wśród lokalnej społeczności.

\section{Skala gminy}

Pierwszym etapem badań była identyfikacja istniejących zasobów funkcjonalno-przestrzennych wraz z ich waloryzacją, przeprowadzona w skali całej gminy. Ta część pracy wykonana była $\mathrm{w}$ ramach badań in situ, popartych szeroką dokumentacją fotograficzną i rysunkową. Następnie dokonano szczegółowej analizy obowiązujących dokumentów planistycznych, ze szczególnym uwzględnieniem możliwości rozwojowych. Oceniono istniejące zapisy i zaproponowano ich weryfikację w odniesieniu do założenia promocji idei synergii rozwojowej wszystkich elementów osadniczych gminy oraz w kontekście budowania wysokiej atrakcyjności oferty turystyczno-wypoczynkowej, podwyższania standardu przestrzeni wspólnych i wprowadzania funkcji sprzyjających integracji mieszkańców.

W badaniach na tym ogólnym etapie prac głównym celem była identyfikacja istniejących walorów wpływających na zwiększenie poczucia tożsamości z miejscem. Drugoplanową kwestią było sprawdzenie potencjału kulturowego gminy, który mógłby stać się zaczynem przemian społeczno-ekonomicznych na analizowanym obszarze. W związku z położeniem gminy w stosunkowo niewielkiej odległości od Poznania oraz przeprowadzonymi wstępnymi analizami zmierzającymi do określenia dominant funkcjonalnych w poszczególnych sołectwach gminy, przyjęto założenie, że gmina Tarnowo Podgórne może stać się celem turystyki weekendowej. Do analizy potencjału turystycznego wykorzystano autorską metodę waloryzacji WID - walory turystyczne, infrastruktura turystyczna i dostępność (Kaźmierczak 2018). Efektem badania była delimitacja stref największej atrakcyjności turystycznej gminy oraz sformułowanie rekomendacji dotyczących przyszłych działań w zakresie tworzenia pożądanej oferty turystycznej, adekwatnej do możliwości i potrzeb gminy. W rezultacie wskazano potrzebę podjęcia następujących działań: 
- dążenie do stworzenia adekwatnej oferty i produktów turystyki weekendowej,

- wzmacnianie roli dwóch największych ośrodków osiedleńczych:

1. Tarnowa Podgórnego nastawionego na rozwój przemysłowo-biznesowy, uwzględniając jednocześnie potrzeby mieszkańców związane $z$ integracją społeczną oraz rozwoju kultury i rekreacji,

2. Przeźmierowa i okolic nastawionych na rozwój usług kultury i handlu oraz turystyki i rekreacji nad Jeziorem Kierskim,

- stworzenie odpowiednich materiałów promocyjnych w postaci map profilowanych dla różnych odbiorców:

1. dla turysty $-\mathrm{z}$ zaznaczeniem obiektów noclegowych, gastronomicznych oraz walorów kulturowych i przyrodniczych, ścieżek rowerowych i przystanków autobusowych,

2. dla przedsiębiorcy - z zaznaczeniem obiektów noclegowych, gastronomicznych, centrum targowo-wystawienniczego oraz obiektów przemysłowych,

3. dla mieszkańca - z zaznaczeniem obiektów kulturowych, administracyjnych, sportowych, usługowych, ścieżek rowerowych i przystanków autobusowych,

- lepsze wykorzystanie obiektów kulturowych, takich jak pałace czy dwory poprzez zapewnienie zaplecza gastronomiczno-noclegowego w/lub obok tych obiektów oraz zwiększenie dostępności komunikacyjnej poprzez wprowadzenie ścieżek rowerowych, parkingów oraz przystanków w niedużej odległości,

- promowanie historii ludzi związanych z gminą poprzez stworzenie ścieżki edukacyjnej np. o wymierających zawodach (kowal, bartnik) lub znanych osobach wywodzących się z Tarnowa Podgórnego.

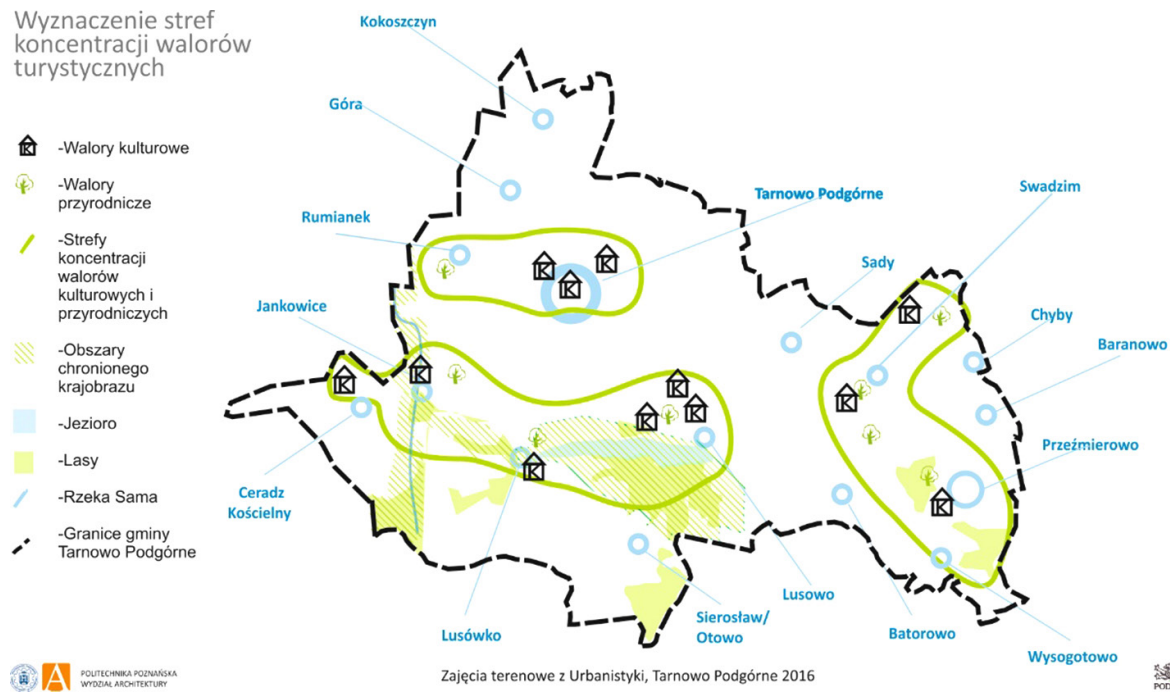

Ryc. 1. Część analityczna dotycząca identyfikacji i oceny stanu istniejącego zasobów funkcjonalno-przestrzennych na obszarze gminy Tarnowo Podgórne - wyznaczenie stref koncentracji walorów turystycznych

Źródło: opracowanie zbiorowe wykonane przez studentów III roku WAPP w ramach przedmiotu plener urbanistyczny pod kierunkiem dr. inż. arch. B. Kaźmierczaka. 


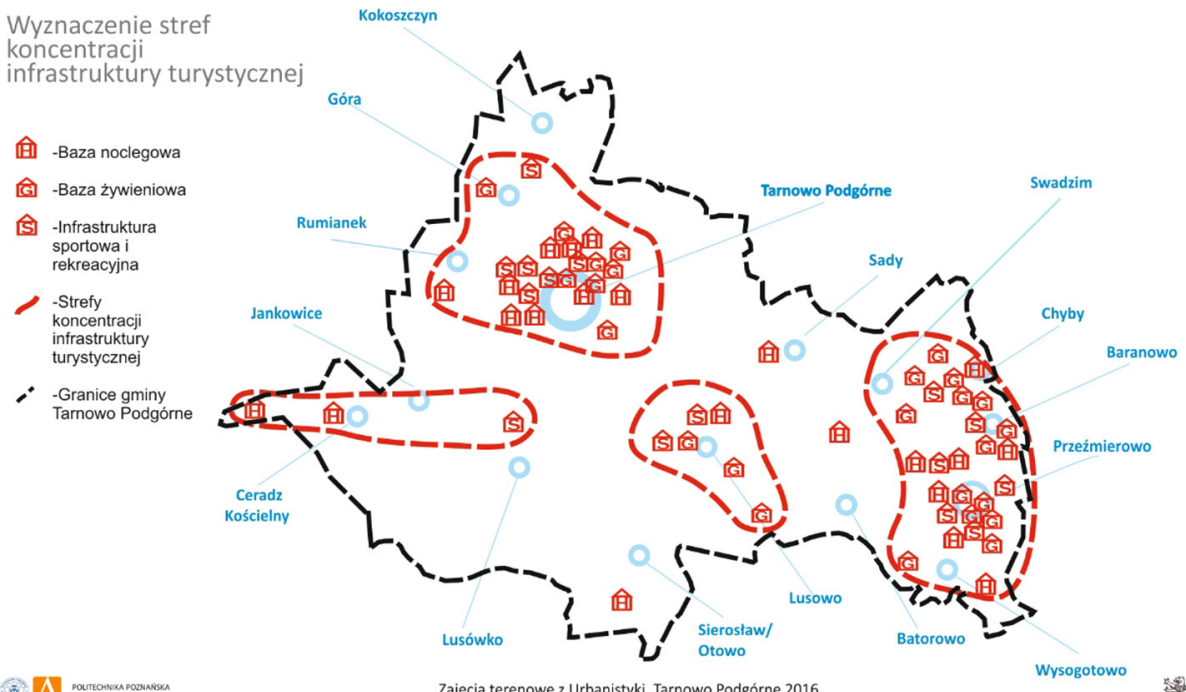

Ryc. 2. Część analityczna dotycząca identyfikacji i oceny stanu istniejącego zasobów funkcjonalno-przestrzennych na obszarze gminy Tarnowo Podgórne - wyznaczenie stref koncentracji infrastruktury turystycznej

Źródło: opracowanie zbiorowe wykonane przez studentów III roku WAPP w ramach przedmiotu plener urbanistyczny pod kierunkiem dr. inż. arch. B. Kaźmierczaka.

\section{Rekomendacje RozWój AGroturYsTKl}

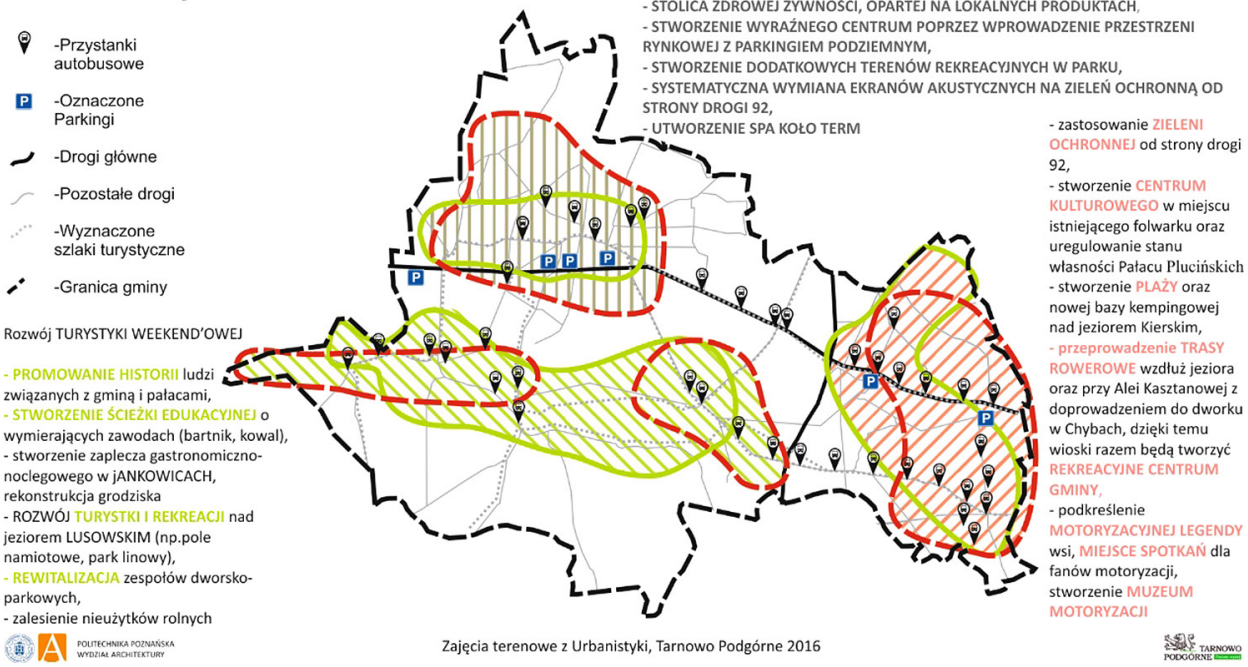

Ryc. 3. Część analityczna dotycząca identyfikacji i oceny stanu istniejącego zasobów funkcjonalno-przestrzennych na obszarze gminy Tarnowo Podgórne - rekomendacje w zakresie rozwoju turystyki weekendowej i agroturystyki

Źródło: opracowanie zbiorowe wykonane przez studentów III roku WAPP w ramach przedmiotu plener urbanistyczny pod kierunkiem dr. inż. arch. B. Kaźmierczaka. 
Uszczegółowieniem rekomendacji w zakresie wspierania rozwoju głównych ośrodków osiedleńczych było wytworzenie we wsi Tarnowo Podgórne atrakcyjnej wizualnie, wygodnej i społecznie uzasadnionej przestrzeni integracji, oferującej niezbędne funkcje do wykreowania miejsca spotkań mieszkańców i osób przyjezdnych.

\section{Skala wsi}

Kolejnym etapem prac było przeprowadzenie wielokryterialnej analizy struktury funkcjonalno-przestrzennej samej wsi Tarnowo Podgórne. W podsumowaniu badań wskazano teren mający najlepszy zestaw cech predestynujących go do przyjęcia funkcji centrotwórczych. Park im. Płk. Jana Wojkiewicza znajduje się w centralnej części wsi przy ulicy Poznańskiej, która jako jedyna w Tarnowie Podgórnym charakteryzuje się zwartą zabudową tworzącą pierzeję. Jednakże, teren ten, oprócz oczywistych zalet, ma wiele cech, które stanowią bariery rozwojowe. Najważniejsze elementy, które zostały ocenione negatywnie, to:

- niemożność wykorzystania inwestycyjnego całego terenu, tworzącego całość przestrzenną, z powodu ograniczenia przez inne występujące tam funkcje zorganizowaną przestrzeń publiczną o charakterze wypoczynkowym z zielenią urządzoną oraz terenami prywatnymi,

- przeznaczenie sąsiadujących terenów na zabudowę mieszkaniową wielorodzinną,

- konieczność korekty układu komunikacyjnego.

W celu uzyskania możliwie najszerszego wachlarza wariantów właściwych rozwiązań projektowych dla wyznaczonego w ramach wcześniejszych badań terenu inwestycyjnego Instytut Haverford Publicznej Socjologii podjął się organizacji konkursu urbanistycznego na zagospodarowanie centrum wsi Tarnowo Podgórne. Podstawą sformułowania wytycznych konkursowych było opracowanie zbiorowe wykonane przez studentów, które stanowiło graficzne podsumowanie istniejących uwarunkowań i wskazanie możliwości rozwojowych funkcji o charakterze użyteczności publicznej (ryc. 4). Plansze z koncepcjami zaprezentowane zostały w pięknym Starym Młynie, położonym w niedalekim sąsiedztwie terenu objętego opracowaniem. Spotkania i dyskusje z mieszkańcami towarzyszące wystawie prac konkursowych stały się także przyczynkiem do rozpoczęcia działań na rzecz integracji lokalnej społeczności, budowania świadomości i wzmocnienia aktywności obywatelskiej. W wyniku plebiscytu wyłoniono zwycięski projekt oraz przyznano dwa wyróżnienia. Ogłoszenie wyników stało się wydarzeniem, w którym wzięli udział nie tylko przedstawiciele środowiska akademickiego i studenci, ale przede wszystkim mieszkańcy, władze gminy i zainteresowani inwestorzy. Pojawili się też przedstawiciele lokalnych mediów, dzięki czemu podjętej współpracy i uzyskanych $\mathrm{w}$ jej ramach rozwiązań projektowych towarzyszyło większe zainteresowanie i satysfakcjonujący zasięg informacyjny.

Zadanie projektowe $\mathrm{w}$ ramach konkursu dotyczyło przedstawienia propozycji aranżacji przestrzennej wyznaczonego fragmentu centrum wsi Tarnowo 
Tarnowo Podgórne - nowe centrum
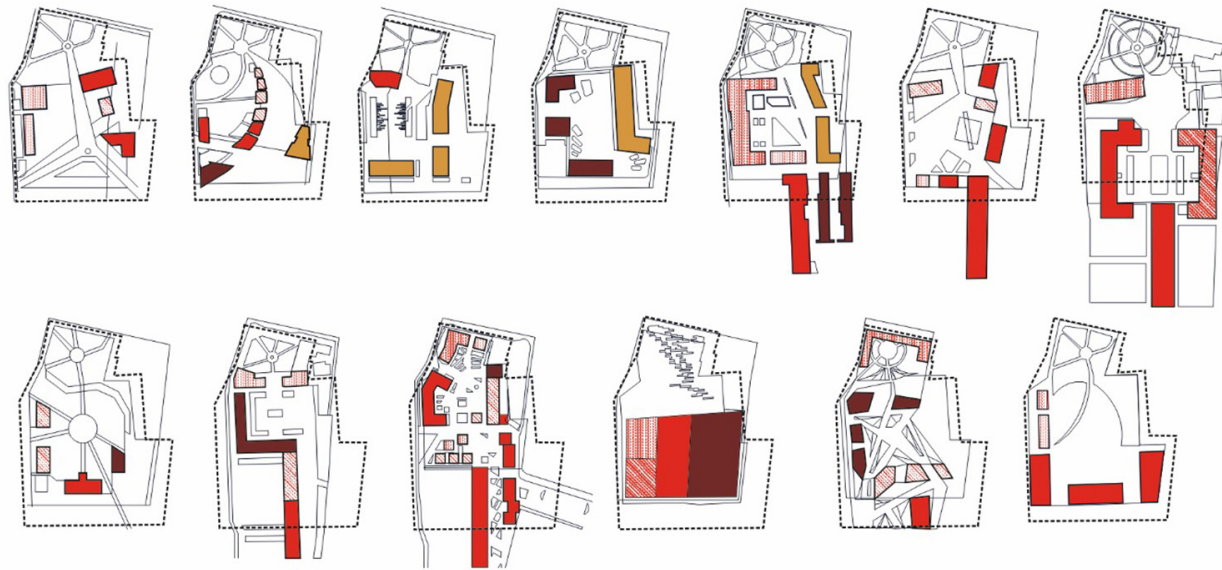

(ii) A

Zajęcia terenowe z Urbanistyki, Tarnowo Podgórne 2016

Ryc. 4. Podsumowanie graficzne części analitycznej dotyczącej oceny możliwości rozwojowych funkcji o charakterze użyteczności publicznej we wsi Tarnowo Podgórne - wyznaczenie obszaru nowego centrum wsi z wariantowym ujęciem możliwości jego zagospodarowania

Źródło: opracowanie zbiorowe wykonane przez studentów III roku WAPP w ramach przedmiotu plener urbanistyczny pod kierunkiem dr. inż. arch. B. Kaźmierczaka.

Podgórne. Celem było zapewnienie przestrzeni zabudowanej o charakterze centrotwórczym (usługa publiczna) wraz z placem i terenem zieleni o charakterze wypoczynkowym. W rezultacie uzyskano trzynaście prac studenckich prezentujących różne rozwiązania funkcjonalne i przestrzenne. W projektach podjęto próbę stworzenia przestrzeni, która ma stanowić „miejsce kompletne” pod względem przestrzennym, funkcjonalnym i społecznym. Opracowane wizje rozwojowe uwzględniały wytyczne kompozycyjno-widokowe zidentyfikowane na podstawie przeprowadzonych analiz oraz zdiagnozowane atuty i problemy wynikające $z$ istniejącego układu komunikacyjnego, zabudowy o różnym charakterze i przeznaczeniu, a także podziału własnościowego.

Dodatkowym, interesującym elementem badań, będącym podsumowaniem uzyskanych $\mathrm{w}$ wyniku konkursu propozycji projektowych, było opracowanie zbiorczego zestawienia proponowanych rozwiązań. Zestawienie to stanowi konkluzję dokonanych obserwacji poczynionych podczas spotkań i prezentacji prac konkursowych na forum lokalnej społeczności. Zamierzeniem było zwiększenie czytelności spodziewanych efektów przestrzennych i społeczno-ekonomicznych wynikających z realizacji poszczególnych koncepcji. Potrzeba lepszej artykulacji konsekwencji wynikających z przyjętych rozwiązań doprowadziła do stworzenia analizy komparatywnej wypracowanych wariantów. Oprócz przedstawienia danych ilościowych, uwzględniających standardowe czynniki, takie jak: powierzchnia zabudowy, powierzchnia biologiczne czynna czy bilans powierzchni 
całkowitej z określoną proporcją poszczególnych funkcji, dokonano również porównania jakościowego, posługując się wypracowanymi w trakcie debat pięcioma kryteriami (tab. 1). Według tego założenia trzynaście prac konkursowych prezentujących różne wizje zagospodarowania wybranego fragmentu centrum wsi Tarnowo Podgórne zostało podzielonych na pięć kategorii wskazujących, jakie elementy były brane pod uwagę przez studentów w procesie projektowym. Największa liczba rozwiązań uwzględniała wydzielenie płyty rynku, co podkreślało ważność i prestiż tego miejsca. Większość projektów proponowała takie rozwiązania kompozycyjne, które akcentowały powiązania widokowe z obiektami lub funkcjami o wyraźnie zdefiniowanym charakterze i ważności zlokalizowanymi w bliskim sąsiedztwie. W projektach sugerowano też wprowadzenie nowych elementów architektonicznych o charakterze dominującym, które uczytelnią układ kompozycyjny, a także zapewnienie w pobliżu funkcji mieszkaniowo-usługowej, która może przyczynić się do zwiększenia żywotności tego terenu.

Tabela 1. Podsumowanie tabelaryczne zawartości trzynastu projektów konkursowych dotyczących nowego centrum wsi Tarnowo Podgórne - ujęcie zbiorcze zaproponowanych rozwiązań z podziałem na pięć kategorii, określających najważniejsze założenia projektowe

\begin{tabular}{|c|c|c|c|c|c|}
\hline $\begin{array}{c}\text { Numer } \\
\text { projektu }\end{array}$ & $\begin{array}{c}\text { Projekt z wy- } \\
\text { dzielona plyta } \\
\text { rynku }\end{array}$ & $\begin{array}{c}\text { Projekt } \\
\text { zuwzglednie- } \\
\text { niem zabudowy } \\
\text { mieszkaniowej }\end{array}$ & $\begin{array}{c}\text { Projekt zotwar- } \\
\text { ciem na istotne } \\
\text { punkty w mie- } \\
\text { ście (mlyn, } \\
\text { cmentarz) }\end{array}$ & $\begin{array}{c}\text { Projekt wpro- } \\
\text { wadzajacy } \\
\text { dominantę }\end{array}$ & $\begin{array}{c}\text { Projekt odno- } \\
\text { szący się do } \\
\text { powierzchni } \\
\text { wiekszej niż } \\
\text { przeznaczona }\end{array}$ \\
\hline 1 & & & & & \\
\hline 2 & & & & & \\
\hline 3 & & & & & \\
\hline 4 & & & & & \\
\hline 5 & & & & & \\
\hline 6 & & & & & \\
\hline 7 & & & & & \\
\hline 8 & & & & & \\
\hline 9 & & & & & \\
\hline 10 & & & & & \\
\hline 11 & & & & & \\
\hline 12 & & & & & \\
\hline 13 & & & & & \\
\hline
\end{tabular}

Źródło: opracowanie zbiorowe wykonane przez studentów III roku WAPP w ramach przedmiotu plener urbanistyczny pod kierunkiem dr. inż. arch. B. Kaźmierczaka.

\section{Skala architektoniczna - projekt Centrum Aktywizacji Obywatelskiej}

Ostatnim krokiem podjętym w ramach przedsięwzięć badawczo-projektowych realizowanych przez Wydział Architektury Politechniki Poznańskiej z Haverford 
Instytutem Publicznej Socjologii było przeprowadzenie drugiego konkursu studenckiego na projekt architektoniczny Centrum Aktywizacji Obywatelskiej. Kompleks obiektów ma być zlokalizowany w opracowanym na wcześniejszym etapie obszarze centrum wsi Tarnowo Podgórne. Wypracowane w poprzednich latach wnioski były podstawą do sformułowania wytycznych konkursowych w zakresie wymogów funkcjonalnych, kompozycyjno-widokowych i technicznych dla projektowanego kompleksu obiektów wraz z jego najbliższym otoczeniem, które ma stanowić inspirująca, atrakcyjną i wysokiej jakości przestrzeń publiczną służącą integracji mieszkańców.

W konkursie wzięło udział siedem zespołów projektowych, które przedstawiły swoje koncepcje przed władzami gminy, gronem profesorskim obu uczelni i przedstawicielami organizatora - Instytutu Haverford. Wszystkie koncepcje projektowe charakteryzowały się wysokim standardem opracowania i bardzo interesującą zawartością merytoryczną, odpowiadającą na wymogi przestrzenne i społeczne, świadczącą o wielkim zaangażowaniu, a także dużej kreatywności studentów. W wyniku obrad jury konkursowego zostały wybrane i nagrodzone trzy prace o najwyższych walorach architektonicznych, które także w największym stopniu odpowiadały uwarunkowaniom prawno-finansowym ich wdrożenia.

Najważniejszym aspektem konkursu i omawianej w artykule wieloletniej współpracy jest aplikacyjność uzyskanych rezultatów badań i przeprowadzonych konkursów w formie realizacji inwestycji - kompleksu obiektów Centrum Aktywizacji Obywatelskiej wraz z otaczającą go przestrzenią publiczną służącą integracji wszystkich mieszkańców. Zwycięska praca ${ }^{4}$ zdobyła duże uznanie wójta gminy Tarnowo Podgórne oraz innych przedstawicieli władz i została nagrodzona nie tylko pierwszym miejscem, ale również możliwością realizacji. Na podstawie wyłonionej w konkursie koncepcji przygotowany został projekt autorstwa biura architektonicznego - Balans Studio M. Ratajczaka. Pierwsze działania już podjęto, a wdrożenie pierwszego etapu inwestycji planowane jest na $2019 \mathrm{r}$.

Poniżej krótkie opisy trzech nagrodzonych prac, wyrażające główne założenia projektowe autorów ${ }^{5}$ :

\section{Nagroda: Zuzanna Wysoczyńska i Karolina Wnuk}

Głównym celem projektowym było stworzenie miejsca, w którym tak samo istotne są: dobra architektura, zieleń i człowiek. W wyniku przyjęcia tych założeń powstała koncepcja, w której architektura spotyka się z naturą, natura z mieszkańcami, a człowiek z drugim człowiekiem. Nazwa projektu „zŁĄKA” powstała poprzez zestawienie ze sobą pierwszych liter najważniejszych haseł, nawiązujących do integracji obywatelskiej: zŁĄczyć, Kształcić i Aktywizować. W odniesieniu

Praca autorstwa studentek III roku I stopnia kształcenia - Zuzanny Wysoczyńskiej i Karoliny Wnuk, zrealizowana pod kierunkiem dr D. Pazder, w ramach przedmiotu architektura krajobrazu.

5 Na podstawie artykułu „Sukces studentów Wydziału Architektury!”, Głos Politechniki, styczeń/ luty 2018, Wydawnictwo Politechniki Poznańskiej, autorstwa D. Pazder, Z. Wysoczyńskiej, K. Wnuk. 


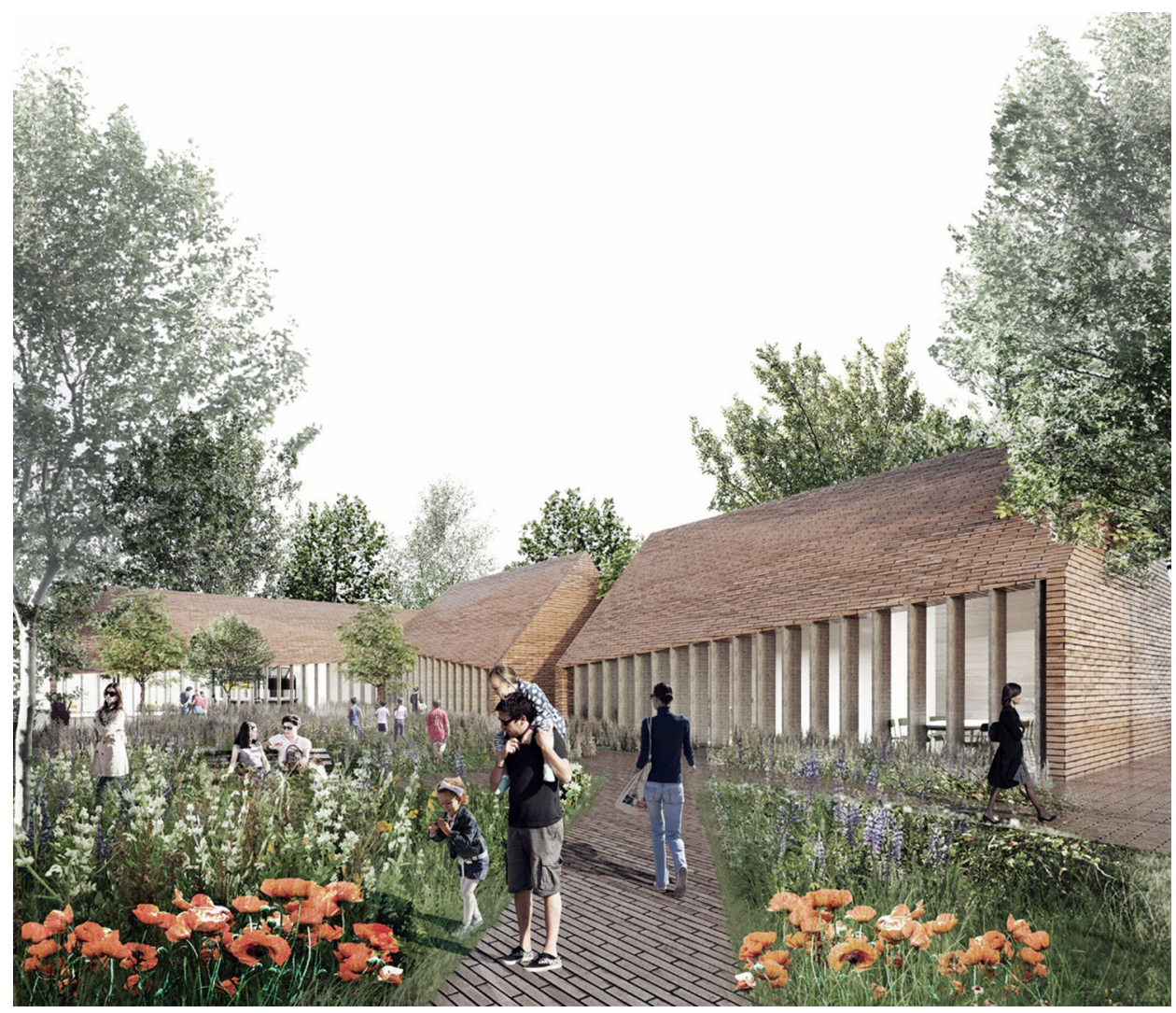

Ryc. 5. I Nagroda: projekt autorstwa studentek: Zuzanny Wysoczyńskiej i Karoliny Wnuk, opracowany $\mathrm{w}$ ramach przedmiotu architektura krajobrazu pod kierunkiem dr inż. arch. D. Pazder

do historii miejsca założenie zostało oparte na układzie wielkopolskiej wsi: zabudowa zwarta zamknięta w czworoboku, dzięki czemu przestrzeń, a nie tylko architektura, stanowi magnes przyciągający przechodniów. Ważnym elementem projektu było wprowadzenie naturalistycznej zieleni oraz naturalnych materiałów. Powstała przestrzeń wewnątrz i na zewnątrz budynku integruje mieszkańców oraz zapewnia szereg możliwości spędzania wolnego czasu w atrakcyjnej i przyjaznej przestrzeni.

\section{Nagroda: Natalia Złotkowska i Barbara Urbańska}

Natura, jedność, styl, serce to hasła, w których zawiera się idea projektowa. Celem było podkreślenie naturalnego uroku przyrody, która jest elementem charakterystycznym Tarnowa Podgórnego. W ramach realizacji tej koncepcji wykorzystano rodzime materiały, dzięki czemu uzyskano efekt homogeniczności obiektu z otoczeniem. Głównym założeniem było odniesienie się do potrzeb i aspiracji odbiorców centrum, uznając, że to człowiek jest najważniejszy w ujęciu 


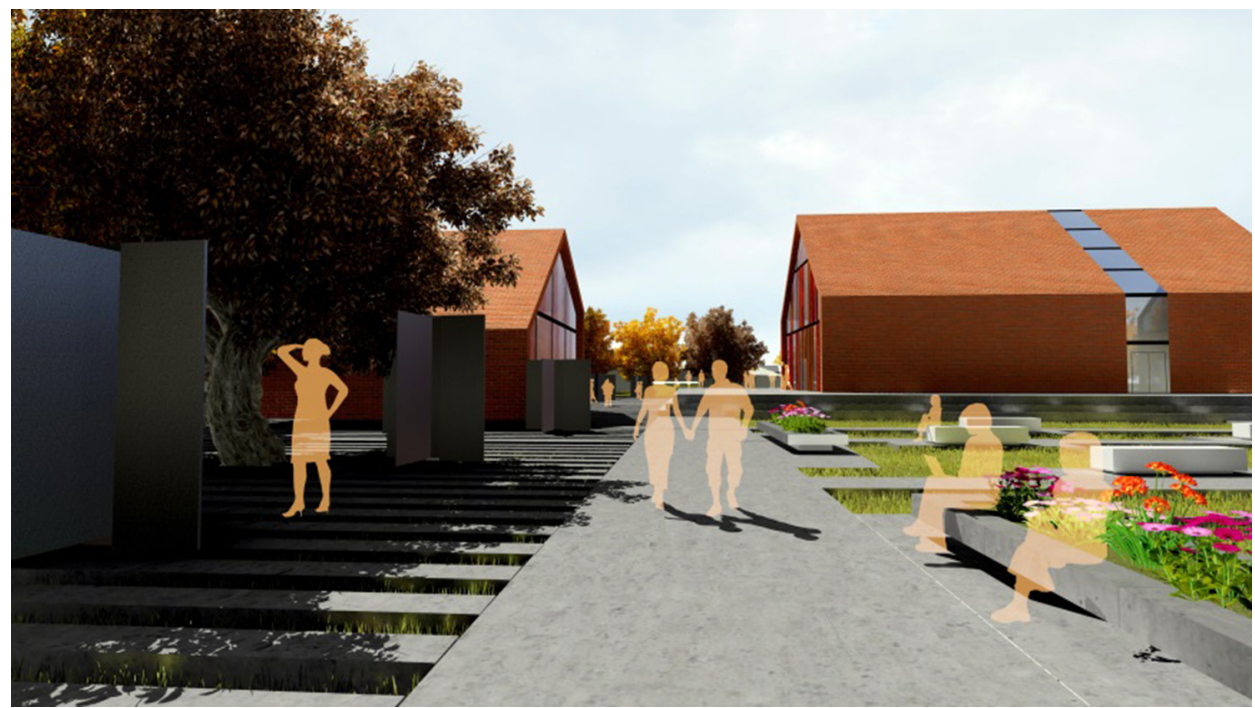

Ryc. 6. II Nagroda: projekt autorstwa studentek: Natalii Złotkowskiej i Barbary Urbańskiej, opracowany w ramach przedmiotu architektura krajobrazu pod kierunkiem dr inż. arch. D. Pazder

projektowania architektonicznego. Proponowane zagospodarowanie obszaru ma za zadanie jednoczyć i integrować mieszkańców - każdy z nich znajdzie coś dla siebie i miło spędzi tu czas. Koncepcja uwzględnia użytkowanie całoroczne, nie tylko obiektu, ale i całego otoczenia kompleksu budynków. Latem oferuje odpoczynek na łonie natury w zacisznym miejscu, zwiedzanie plenerowej galerii sztuki dla dorosłych oraz dzieci, a także miejsca zabaw dla najmłodszych, które znajdują się w wygodnej odległości od ogródków kawiarnianych. Wieczorem jest możliwość organizowania różnego rodzaju imprez i koncertów. Zimą wspólne ubieranie choinki przez mieszkańców lub nauka malarstwa i jazdy na łyżwach dla najmłodszych. Spotkania w gronie najbliższych, codzienne zakupy na stoiskach oferujących lokalne produkty, rozmowy biznesowe, szkolenia. Takiego miejsca nie można raz odwiedzić, tutaj wraca się nieustannie, zostawiając część siebie i swoje serce.

\section{Nagroda: Katarzyna Wróbel i Mikołaj Zydorowicz}

Mając na uwadze różnorodność użytkowników, którzy będą odwiedzać nowo projektowany obiekt, stworzono koncepcję przestrzeni o rozmaitym wyrazie wizualnym. Pod względem funkcji zaprojektowany układ będzie dostarczać rozrywki, relaksu, zapewniać miejsca do pracy, a przede wszystkim stanowić będzie miejsce społecznej integracji i aktywizacji. Mała architektura oraz rysunek nawierzchni, ułożone według wyznaczonego kierunku urbanistycznego, zapraszają do przyjaznej przestrzeni publicznej, gdzie mieszkańcy będą mogli usiąść na specjalnie zaprojektowanych hamakach i spędzać czas na rozmowach i odpoczynku. 


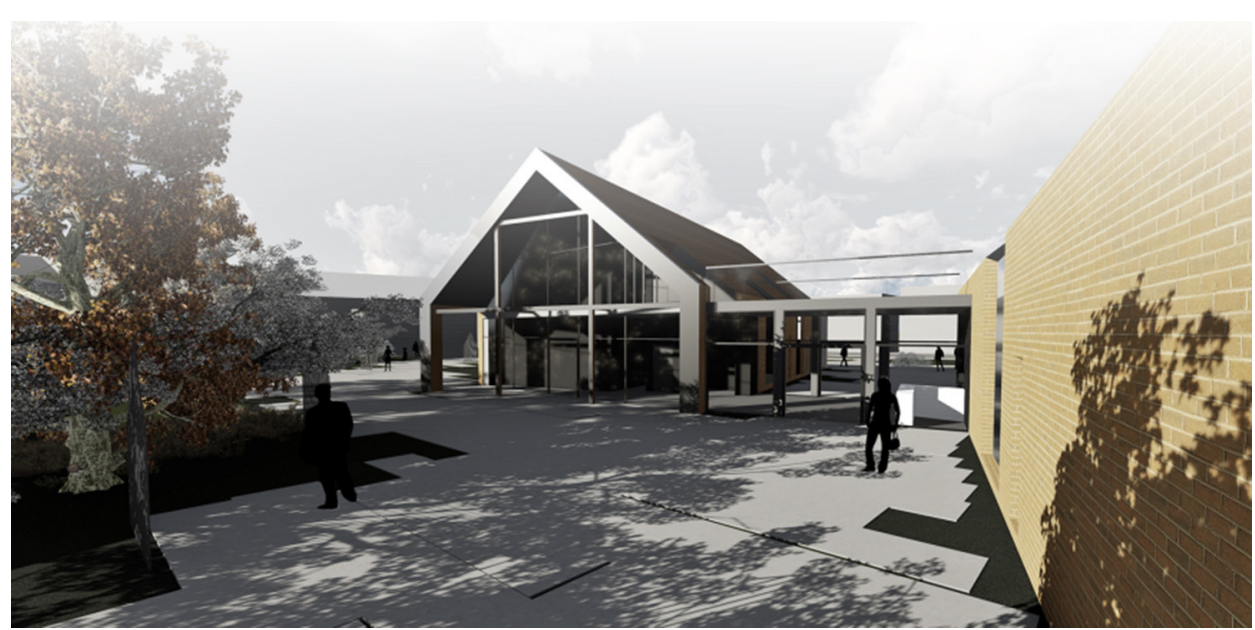

Ryc. 7. III Nagroda: projekt autorstwa studentów: Katarzyny Wróbel i Mikołaja Zydorowicza, opracowany $\mathrm{w}$ ramach przedmiotu architektura krajobrazu pod kierunkiem dr inż. arch. D. Pazder

Stworzenie takiego miejsca, jakiego dotąd brakowało w Tarnowie Podgórnym, powinno wyzwolić w mieszkańcach chęć aktywizacji społecznej, do czego dodatkowo zachęcać będzie zlokalizowana w budynkach kawiarnia oraz muzeum. Ideą było zapewnienie miejsca prospołecznego, intuicyjnie odczuwalnego miejsca spotkań - spotkań nie tylko z innymi mieszkańcami, ale również ze sztuką. Stąd nazwa „publiczna strefa sztuki".

\section{Podsumowanie}

Zaprezentowane $\mathrm{w}$ artykule metody nauczania wykorzystujące idee collaborative i problem-based learning stanowią narzędzia, które w znaczącym zakresie mogą wzbogacić proces dydaktyczny. Największą korzyścią jest fakt opracowywania przez studentów rozwiązań, które mają szansę na wdrożenie, a także wzbogacenie kolejnych faz powstawania koncepcji projektowych o realną współpracę z włodarzami i lokalnymi społecznościami. Ważne jest włączenie lokalnych społeczności na co najmniej dwóch etapach: początkowym - identyfikacji potrzeb i końcowym - podczas oceny projektów przez te gremia w drodze konkursu lub w formie plebiscytu.

Ze strony władz samorządowych współpraca z ośrodkami akademickimi może stanowić bodziec i skuteczny instrument służący promocji wiedzy w zakresie planowania przestrzennego, a także upowszechniania idei planowania partycypacyjnego. Organizacja wystaw pokonkursowych, które pozwalają na wnikliwą identyfikację możliwości rozwojowych miasta lub gminy w różnych skalach problemowych może okazać się przydatna pod kątem upowszechniania idei tworzenia miejsc kompletnych oraz przestrzeni wspólnej, która jest przyjazna i zaspokajająca potrzeby mieszkańców. Taka współpraca może stanowić przyczynek 
do rozpoczęcia otwartej dyskusji na temat atutów i mankamentów oraz szans i ograniczeń dla rozwoju określonej przestrzeni w mieście lub gminie, jednocześnie stanowiąc wkład w wypracowanie spójnej wizji rozwojowej, uwzględniającej aspiracje i preferencje lokalnych społeczności. Zdaniem autorów jest to również instrument służący upowszechnianiu partycypacyjnego modelu planistycznego, który poprzez czytelną i atrakcyjną formę graficzną może wzbudzać zainteresowanie mieszkańców, zachęcając tym samym do bardziej aktywnego zaangażowania w działalność na rzecz polepszenia jakości lokalnej oferty przestrzennej. Jest to szczególnie przydatne narzędzie w kontekście obecnych polskich uwarunkowań planistycznych, w których paradygmat planowania partycypacyjnego wciąż jeszcze nie jest $\mathrm{w}$ pełni realizowany, a poziom uspołecznienia procesu pokazuje, że sfera ta nadal wymaga działań mających na celu podkreślenie jej ważności, poprzez różne formy uczestnictwa w procesie planistycznym, zarówno wśród włodarzy, jak i mieszkańców. Według autorów współpraca ośrodków akademickich z władzami terytorialnymi, organizacjami pozarządowymi i mieszkańcami jest także skutecznym sposobem promocji postaw obywatelskich i odpowiedzialności za przestrzeń publiczną, w obrębie której wszyscy odbiorcy są tak samo ważni.

\section{Literatura}

Augé M. 1995. Non-Places. Introduction to an Anthropology of Supermodernity, Verso, London.

Canter D. 1977. The Psychology of Place. London.

Montgomery J. 2003. Cultural Quarters as Mechanism for Urban Regeneration. Pt 1. Conceptualizing Cultural Quarters. Planning, Practice and Research, 18, 4.

Clarke A.J. 2016. The New Design Ethnographers 1968-1974: Towards a Critical Historiography of Design Anthropology. [W:] R.Ch. Smith, K.T. Vangkilde, M.G. Kjærsgaard, T. Otto, J. Halse, T. Binder (red.), Design Anthropological Futures. London, New York.

Dober R.P. 1992. Campus design. New York.

Dovey K. 1985. An ecology of place and placemaking: Structures, processes, knots of meaning. [W:] K. Dovey, P. Downtown, G. Missingham (red.), Place and Placemaking. Proceedings of the PAPER 85 Conference. Australia, Melbourne.

Doxiadis C.A. 1968. Ekistics: An Introduction to the Science of Human Settlements. New York.

Halse J., Boffi L. 2016. Design Interventions as a Form of Inquiry. [W:] R.Ch. Smith, K.T. Vangkilde, M.G. Kjærsgaard, T. Otto, J. Halse, T. Binder (red.), Design Anthropological Futures. London, New York.

Kaźmierczak B. 2018. Turystyka zrównoważona czynnikiem aktywizacji małych miast. Wydawnictwo Politechniki Poznańskiej, Poznań.

Kaźmierczak B., Matusewicz T., Pazder D. 2018. Sztuka w przestrzeni miasta jako środek kreacji i aktywizacji społecznej przestrzeni publicznych miasta. Na przykładzie studialnym Poznania. Architecturae et Artibus, 9(4). Białystok.

Kaźmierczak B., Pazder D. 2018. Complete places visioning - collaborative and problem-based learning in urban planning. Example of the Faculty of Architecture Poznan University of Technology in Poland. European Journal of Social Sciences Education and Research by De Gruyter Journals, 5, 3: September-December.

Kaźmierczak B., Pazder D. 2018. Landscape restoration as a tool of high quality public space creation - case study of Wilda district in Poznan, Poland. Scholars Journal of Arts, Humanities and Social Sciences, 6, 7 .

Pazder D. 2018. Obszary kreatywności - creative syntax jako czynnik ożywiania śródmieść. Monografia. Wydawnictwo Politechniki Poznańskiej, Poznań. 
Pazder D., Wnuk K., Wysoczyńska Z. 2018. Sukces studentów Wydziału Architektury!. Głos Politechniki, styczeń/luty 2018. Wydawnictwo Politechniki Poznańskiej.

Sanetra-Szeliga J. 2016. Kultura i rozwój miast. Wyzwania XXI wieku. [W:] K. Broński, R. Kusek, J. Sanetra-Szeliga (red.), Pamięć, wybór i tożsamość. Szkice o mieście. Kraków.

Zbierska-Salameh S. 2017. Centrum Tarnowa coraz bliżej! Bezpłatne pismo Gminy Tarnowo Podgórne, 7(316): lipiec.

\title{
Strony internetowe
}

https://www.pps.org/article/what-is-placemaking

\section{The design of "complete places" in process of teaching of urban planning}

\begin{abstract}
The paper presents selected issues related to the design of "complete places" - understood as friendly and socially attractive public spaces. The importance participatory planning and collaborative urban planning process is emphasized, because in Authors' opinion that is the only way to elaborate spatial solutions meeting real social needs. The article presents the idea of complete places visioning which is an element of the didactic process carried out at the Faculty of Architecture of the Poznan University of Technology and as part of cooperation with the external environment. Presented example of a problem-based and collaborative learning seems to be a very useful tool for promoting the idea of socialized planning aiming at quality of public space improvement. There is presented a case study of long-term cooperation between academic institutes and the municipality of Tarnowo Podgórne. This cooperation turned out to be very successful thus it resulted in the erection of a complex of buildings of Civic Activation Centre in the middle of the village which is to integrate local community.
\end{abstract}

Keywords: complete places visioning, participatory planning, collaborative and problem-based urban planning 